\title{
REVIEWS
}


Jean-Marc Dreyfus and Élisabeth Anstett, (eds), Human Remains in Society: Curation and Exhibition in the Aftermath of Genocide and Mass-Violence (Manchester: Manchester University Press, 2016), 268 pp, open access, ISBN 9781526129338

Human Remains in Society is the fifth volume in the Human Remains and Violence Series published by Manchester University Press since 2014. The series evolved out of the European Research Council-funded research programme on Corpses of Mass Violence and Genocide, which ran from 2012 to $2016 .{ }^{1}$ Like almost all the books in the series, this volume is an edited collection curated by the project leaders and series editors, Élisabeth Anstett and Jean-Marc Dreyfus.

Operating from the premise that, despite manifold research into the body and contexts of mass violence, these fields of study have only rarely been thought together, Anstett and Dreyfus aim to provide interdisciplinary approaches to the social and cultural treatment and representation of dead bodies linked to mass violence. The two editors examine the treatment of bodies in contexts of mass violence in terms of three distinct phases: their destruction; their search and identification; and their return to society. This particular volume focuses on the last stage, although, as all the contributions show, neither the passages and paths of return nor their interpretation can be separated from the circumstances that caused the deaths in question.

As the editors ask in their introduction: 'Which actors, then, are involved in the reinscription within societies of human remains resulting from mass violence and genocide? What is at stake in the way these remains are treated, and what are the logics that govern this treatment?' (p. 2). Through contributions dealing with very diverse geographical and political contexts, analyses of these questions are offered. Recurring themes across the book centre on human remains as evidence; their role in political and ideological struggles; forms of commemoration, and their personalising or anonymising effects; the frictions and correlations between claims made by communities, individuals and states in the process of reintegrating remains into society; and the often-disparate views on what constitutes 'dignified treatment' of remains.

Several chapters focus on the aftermath of the Holocaust and evolving debates around the treatment and reburial of the remains of victims. Caroline Sturdy Colls, the only forensic archaeologist among the contributors, introduces her investigations on the sites of extermination and labour camps in Treblinka, Poland. She points out that many burial sites of Holocaust victims have not been found or marked, and only few have been subjected to systematic archaeological examinations, due to opposition to examinations based on religious beliefs and regulations, financial and logistical restrictions or difficulties of access. Sturdy Colls makes a strong case for the possibility of ethically conducted forensic research, that respects the needs and limits

1 See http://www.corpsesofmassviolence.eu/ (accessed 13 September 2018). 
of all communities involved. Her text is productively amended by David Deutsch's evaluation of post-war rabbinical responsas discussing the possible exhumation and reburial of mass graves.

In Gaetano Dato's and Devlin Scofield's chapters, the remains of Holocaust victims and their commemoration are shown to lie at the centre of territorial claims and atonement politics in post-war Europe. More contemporary negotiations of national belonging form part of Zuzana Dziuban's analysis of the history of the site of the extermination camp in Bełżec, Poland. In her view, the current form of memorialisation at the site, and continued anti-Semitism, contribute to re-inscribing fixed identities on people as either Jewish victims or Polish citizens. Material processes have begun to trouble this segregation, however. Citing a study conducted in the late 1990s which confirmed that water in the region was being contaminated by decomposing corpses entering the groundwater, Dziuban maintains that 'the material circulation of remains, which resists and blurs the identity-based divisions separating them, designates the "Poles" - at least as processual and relational bodies - to act as sarcophagi for the otherwise unburiable dead' (p. 56).

National politics also stand at the centre of David Anderson and Paul Lane's contribution. As they show, the commemoration of victims of the Mau Mau rebellion in Kenya is complicated by the fact that many Kenyans were killed for appearing to be loyal to the colonial government, thereby rendering the integration of their remains into national memory politics almost impossible. Some of these remains are still stored in Nairobi Museum's Osteology Department, having been donated to its colonial predecessor, the Coryndon Museum, in 1959, by the then-chief police pathologist. The 'unusual collection' was 'used as evidence against the Mau Mau by Her Majesty's Police', yet no coherent documentation of this usage or conditions referring to the transfer of the collection have yet been found in the archives (pp. 22, 24). Unfortunately, Anderson and Lane limit their analysis of this complex situation to framing the museum space as a continued violation of the remains. They propose to end this violence by tracing descendants of the victims and enabling burials. Further interrogation of the entanglement between colonial forensic violence and the contemporary difficulties of dealing with these remains might have fostered more awareness in the authors of their own role in negotiating where the remains belong and which methodologies might be appropriate for such sensitive debates.

Conflicted claims concerning the position of human remains in the re-imagining of a nation are also at play in Vilho Amukwaya Shigwedha's case study. Shigwedha provides an account of the history and politics around the repatriation of the remains of Nama and Herero from Germany to Namibia in recent years. Here, the remains have been framed as evidence of atrocities committed by the German colonial empire, and play an important role in Namibia's demands for an official apology and reparations from the German state. For these reasons, an argument has been made against their reburial, resulting in the repatriated remains being stored in the National Museum of Namibia in Windhoek. Shigwedha, in contrast to Anderson and Lane, builds his analysis of the contemporary situation on a careful revision of the 
colonial violence that led to the genocide of Nama and Herero communities between 1904 and 1908, and its intrinsic connection to racialised anthropological research.

Through observing the effects that the display of a skeleton of a Beothuk child, and its subsequent disappearance, had on local memory politics in the city of St John's in Newfoundland, Canada, John Harries highlights the power of absence in memorialisation processes. The remains were removed from the local museum in the 1970s. Harries interviewed people who had seen the skeleton on display when they themselves were children. Many recounted identifying with the child, which Harries describes as 'something of an undoing of histories of violence and dispossession' ( $\mathrm{p}$. 239). Looking back, however, the interviewees expressed feelings of remorse and sorrow. Harries argues that it is precisely the absence of the remains that allows for the acknowledgement of the violent histories they represented. He also alludes to another layer of discomfort in this conclusion, owing to the extermination of Beothuk people through colonial violence and the resulting absence of living Beothuk people in contemporary society. It is in this violent void that the acknowledgement of the atrocities seems to be enabled.

Shigwedha's and Harries' chapters both provide enriching insights into the legacies of physical anthropology, its constructions of race, and its deep entanglement with colonial violence and dispossession. However, there remains a question of whether these contexts of structural violence would also have a place in the volume if they had to be framed less unambiguously as forms of 'mass violence.' Their inclusion seems to be based on the fact that we are dealing with the remains of people who were subjected to genocidal warfare. Where are the many who died as a result of colonial violence or slavery positioned in the category of mass violence?

Anstett and Dreyfus focus explicitly on the intentional production of the civilian dead on a mass scale' in the twentieth century (p. 1-2). However, they position the birth of physical anthropology as inextricably linked with genocides and crimes against humanity', and state that while 'the forensic scientists whose work is analysed in this volume no longer have a racialist agenda, genocides and episodes of mass violence are still both the source and the product of their knowledge' (p. 5). Considering this emphasis on the centrality of scientific racism, it remains little scrutinised in the book. Also, by focusing on the twentieth century, its evolvement is relegated to $a$ priori of lesser interest. A slight underestimation of the legacies of scientific racism and colonialism in the conceptualisation of the volume also shows in the editors' claim that it was the visibility of human remains on display, in religious and scientific contexts, that led to a new thinking about their proper treatment, resulting in codes of ethics and laws such as the UK's Human Tissue Act of 2004.

Claims made by indigenous people, demanding that their ancestors be returned from museums and academic collections, forming what has been called the repatriation movement since the 1960s and 1970s, are left out of this (admittedly very short) narrative. To avoid this being perceived as an omission, it might have sufficed had the editors referenced some of the vast literature that deals with debates around the display and treatment of human remains appropriated for science and spectacle in 
colonial contexts. Some of this literature also analyses the ways in which sex and gender feature in these violent histories, another aspect that is absent from this volume. ${ }^{2}$ Such references could also have helped highlight just how valuable the volumes that form part of the Human Remains in Society Series are to the field. Indeed, the interdisciplinary and contemporary approach links perspectives that are rarely thought through together, thereby enabling new analyses of the cultural, social and political contexts of the treatment of dead bodies.

\section{Sophie Schasiepen}

Department of History, University of the Western Cape

2 See, for example, Devon A. Mihesuah (ed.), Repatriation Reader: Who Owns American Indian Remains? (Lincoln, NE: University of Nebraska Press, 2000), Cressida Fforde and Jane Hubert (eds), The Dead and their Possessions, Repatriation in Principle, Policy and Practice (London: Routledge, 2002), Ciraj Rassool and Patricia Hayes, 'Science and the Spectacle: /Khanako's South Africa, 1936-1937', in Wendy Woodward, Patricia Hayes and Gary Minkley (eds), Deep hiStories: Gender and Colonialism in Southern Africa (Amsterdam: Rodopi, 2002), Paul Turnbull and Michael Pickering (eds), The Long Way Home. The Meanings and Values of Repatriation (New York: Berghahn, 2010). 